\title{
Backstaging the teacher: On learner-driven, school-driven and data-driven change in educational technology discourse
}

\section{KEYWORDS}

educational discourse, discourse analysis, digital education, educational technology, edtech, hegemony, datafication

\begin{abstract}
Macgilchrist Felicitas, Backstaging the teacher: On learner-driven, school-driven and data-driven change in educational technology discourse. Kultura - Społeczeństwo - Edukacja nr 2(12) 2017, Poznań 2017, pp. 83-103, Adam Mickiewicz University Press. ISSN 2300-0422. DOI 10.14746/kse.2017.12.4.
\end{abstract}

As digital technologies become more prominent in schools, and a host of new media products appear in classrooms, critical questions are being asked about the erasure of power and politics in contemporary education. To explore the discourse on digital education, this paper draws on discourse analysis of ethnographic interviews with for-profit and non-profit organizations in the field. It asks (i) what industry insiders describe as driving change in contemporary educational technology (edtech), and (ii) whether new actors/technologies shaping a novel educational hegemony, and if so, what this hegemony looks like. Initial findings suggest that while the teacher was seen as key to driving change in printed educational materials, three different discourses appear when describing change in today's educational technology. In the first, learners drive change; the focus lies on the individual dimension. In the second, schools drive change; the systemic dimension. In the third, data drive change; the analytics dimension. Linking these three discourses is a shift from "education" to "learning". The accounts of educational technology simultaneously advocate for improving opportunities for all students, especially weaker or disadvantaged learners, and also strengthen the hegemonic shift across policy and practice towards an instrumental understanding of education. Overall, the paper suggests that power and politics are by no means erased from the edtech industry's accounts of digital technologies and datafication. The socio-material affordances engineered into the technologies invite particular teaching practices and thus affect power relations in education. 
The field of digital education is often criticised for assuming that technology is neutral, or that "by focusing on 'what's new', [it] has "failed to ask 'who has power" (Emejulu and McGregor, 2016: 3). However, if we agree with Neil Selwyn, then the relationship between education and technology touches on the "fundamentally political questions that are always asked of education and society - that is, questions of what education is, and what education should be" (Selwyn, 2012: 217). In this article, I argue that although scholarship, advertising and journalism may often assume technology is apolitical, the people involved in designing and developing educational technology by no means do so. Instead, while focusing on "what's new" they simultaneously formulate eminently political views on the technology they are shaping and the power effects it may have. This paper focuses on three interrelated issues arising in conversations with companies who produce digital tools and resources for use in school: First, discourses on who or what is driving change in contemporary educational technology. Second, an overarching shift in understanding "education" as "learning". Third, what follows from this for the imagined relationship between teachers and technology, and how that relationship will shape the future of education.

\section{Context}

In the not-too-distant past, educational media were largely print-based. Although there were CD-ROMS, online materials, web 2.0 and interactive apps, the vast majority of materials produced for use in formal education, and certainly in schools, were textbooks and other printed materials. For these materials, one set was purchased or copied and distributed to all students in class. Only major educational publishers (whether for-profit or state-run) could make the large investments necessary to create content. Some publishers were producing differentiated materials so that weaker and stronger students could work through topics with material aimed at supporting them in the best way possible and enabling them to work at different levels. However, the overall strategy of developing published materials could, as one participant in this study suggested, be summarized as a "one size fits none" approach to the classroom. Teachers, rather than producers, were making the decisions on how to personalize, individualize and tailor the materials to the students in their classrooms, because teachers had the most intimate knowledge of their students' abilities, needs and motivations. At that time, publishers had teachers in their minds as their imagined primary audience when developing materials; teachers were arguably driving the content which educational publishers were 
producing for schools (Sammler, et al. 2016). As one former editor has critiqued, however, it was often a particular imagined teacher: "Publishers are incentivized to create materials that appeal to teachers who don't want to change" (Jobrack, 2011: xix). Students as end users have always been important, but teachers, schools, school boards and districts were seen as the gatekeepers between educational publisher and student (Macgilchrist, 2011).

The current juncture is seeing a leap in the breadth of digital materials available for, and being used in, schools. In 2016, for instance, McGraw-Hill, one of the leading educational publishers in the US, made over $56 \%$ of its profit from digital products, the first time over half its revenue was generated by the digital (rather than print) side of the business (McGraw-Hill Education, 2017: 5). The focus of this article is on schools in the United States of America, which has seen various iterations in its approach to digital technology in schools. Hardware was an initial priority. Interactive whiteboards, iPads, Chromebooks, etc. have made major inroads into K-12 (i.e. elementary and high school level) education. Alongside this hardware, digital textbooks were adopted, including open textbooks (Okamoto 2013), and students were encouraged to use the web to find information for projects. The textbooks were mostly digitized versions of the print textbook (and this is largely the case worldwide, with several Ministries of Education enabling free access to PDFs of the entire stock of textbooks across the school curricula via their websites, e.g. Syria, Ecuador, Brazil, Mexico or Iran, cf. Macgilchrist, 2017). The web was mainly used for Google or Wikipedia searches, with students invariably following up on the first hits they found, rather than digging deeper and checking sources (cf. Hodel, 2013). Dedicated early adopter teachers were devising innovative pedagogies for their classes, but "digital practices" remained at an individual teacher level.

The conversation today revolves around novel pedagogies which enable schools or districts to make the most of digital tools and resources (e.g. Clapp et al., 2017; Dezuanni, O’Mara, and Beavis, 2015). There is widespread recognition that simply using computers, laptops, tablets, phones and interactive whiteboards is not enough to significantly transform teaching and learning. Nor is it enough to have innovative pedagogies driven by single teachers who exploit themselves as cognitive labourers in this new digital education system (Selwyn, Nemorin, and Johnson, 2016). Although remaining on the margins of mainstream discourse on "edtech" (educational technology), vocal advocates are discussing critical digital pedagogy, critical design literacy or radical digital citizenship, where the emphasis is on a way of being in the world which goes beyond making students 'effective' participants in a digital world, and instead fosters a critical approach and encour- 
ages collective action for social justice (e.g. Emejulu and McGregor, 2016; Pangrazio, 2016; Strommel, 2014).

With the increasing importance of the digital, two observations can be made: First, the designers of educational materials now have direct access to students and individual experimental teachers. The teacher body no longer has the same gatekeeper role it previously had. Second, this makes it more feasible for new players to develop products for schools. For several years, observers have been asking if and how these new actors are shifting the terrain of education. There has been much speculation about this issue; theoretical models have been proposed (Höhne, 2015), but there has been little empirically grounded study of how the industry itself accounts for its practices. This article picks up this core issue and translates it into research questions on two levels: (1) What does the edtech industry position as driving change in contemporary educational media? (2) Are these new actors/technologies shaping a novel educational hegemony? And if so, what does this hegemony look like? It draws on interviews with industry insiders, teasing out three types of discourse about education in the digital world, and reflecting on the changes and continuities with which these new actors are entangled.

\section{Methodology and methods}

Any study responding to these questions can, of course, only be a snapshot of current practice. Indeed, the focus here is not on observable practices in today's schools, but on accounts of these practices. This paper is part of a larger study on the "discourse of edtech", which considers educational policy, media discourse and edtech development in Germany and the US. The basis for this article is 12 indepth interviews with CEOs, managers, strategists, lawyers, educational advocates and researchers at organizations related to edtech, based in the US. In March and April 2017, I spoke for between one and two hours with non-profit and for-profit organizations; with smaller companies developing one single learning app, and multi-billion dollar companies with a broad portfolio of print and digital products. Participants were identified by drawing on the technology literature on successful edtech companies, and the online presence of vocal advocates in the field of educational data and student privacy. ${ }^{1}$ In identifying three discourses, I do not mean

\footnotetext{
${ }^{1}$ In support of open science, but within the constraints of a research ethics of informed consent agreements and anonymization, I am happy to let readers see the co-text and context of the transcripts on which I draw in this article. Interested readers should contact me by email.
} 
to claim that these are the only discourses on driving change in digital education. However, I do suggest that these discourses resonate with broader discussions on edtech today.

To this study, I bring an ethnographic sensibility and a discourse analytical lens. The ethnographic sensibility means I had a set of questions to guide the interviews, but the conversations flowed around the specifics of the person with whom I was speaking. I see any interview first and foremost as an interpersonal exchange (DeVault and McCoy 2006); my person is also a research instrument, and any attempt to reduce my presence, i.e. to be objective or distanced, negates the importance of this mental-material-semiotic interaction (Adams, St. Pierre, 2011; Lenz Taguchi, 2012). Thus, I am - as an ethnographer - fully part of the exchange, and co-construct (with my verbal and non-verbal cues) the narrative which my interview partner is telling. An ethnographic sensibility also means that I aim to use vignettes, short stories or detailed case studies to shed light on fundamental societal issues, such as innovation, datafication or what counts as valuable education. The goal is to tease out how specific discursive fragments or situated practices are entangled with social-cultural, political, economic, historic and material orderings, and how these orderings write themselves into the specific fragments and practices.

The discourse analytical lens is core to this study: The guiding questions above are discourse analytical. On the one hand, the article aims to describe different accounts of educational change today, and to analyse conflicts among various "discourses", where discourse refers to way of speaking and doing which privilege certain ways of living and being, and render others undesirable. Through discourse, certain ideas become common-sense and others become odd; discourses create subject positions at which people are addressed (e.g. as child, pupil, student or learner) and from which they are invited/expected to act. I understand discourse, in this sense, as "the primary terrain of the constitution of objectivity as such" (Laclau, 2005: 68). On the other hand, the article aims to describe the overarching "hegemonic configuration" in which these conflicts play out, where hegemony refers to "a whole body of practices and expectations, over the whole of living"; it is "a lived system of meanings and values - constitutive and constituting - which as they are experienced as practices appear as reciprocally confirming" (Williams, 1977: 110). Although different sets of ideas, which can be bundled together as "discourses", conflict with one another, these conflicts play out within an overarching lived system of shared meanings and values. This system is itself constantly enacted through everyday practices. 
Where ethnography and discourse analysis potentially clash is their differing levels of empathy: Where ethnography generally aims to understand the meanings made by participants, discourse analysis aims to critique hegemonic meaningmaking. As my ethnographic self is generating insights with my interview partners, I am excited about the educational technologies which they are developing. I appreciate their goals of, for instance, improving the learning experience, increasing equal opportunity and supporting teachers and school reform (see below). I see clear evidence that their products are serving these goals, and I see a richness to the field of educational media which was not there several years ago, and which benefits students, teachers and schools. Yet as a critical discourse analyst, I also question the way in which the values and priorities of education are subtly shifting in line with the material affordances of these digital technologies (see below). My overall research aim is to leave this tension unresolved (Law et al., 2013); to avoid "tidying" up my analysis to either account for participants' meaning making, thus ignoring the broader picture of hegemony, or to ignore the passion for educational change which I see in these participants in favour of a mono-dimensional critique of techno-solutionism. Both aspects play into the changes and continuities of formal education today, and I believe that taking both into account is necessary if we want to understand current practices.

\section{Discourses of change}

Different positions were visible in each interview. There was no one single discourse associated with one single speaker, although some participants leaned more strongly towards one position.

\section{Discourse 1: Learner-driven change, the individual dimension}

"I never liked school" said one chief executive officer (CEO). Another CEO was revising for his GMAT exam and getting frustrated with his printed materials; he wanted a tool for his iPhone which helped him - as a learner - to learn in a more fun way. A senior manager said: "Well, what is the best possible learning experience you can have? What's the most valuable thing you can have? As a learner? It is to have a personal tutor, right?" But a personal tutor who knows you very well would be far too expensive to scale up, so the next best thing is a digital person tutor.

When I asked about the core challenges currently facing the company, one chief operating officer (COO) noted that shifting their focus away from the learner 
was a challenge: "Because we were learner-focused for the first five years of our company, we had been able to create a learning experience, which is absolutely best in class. So that has helped us to sell to our clients, even though we don't have the same swanky features that a lot of other learning management systems might have". A core challenge for this company now was to make the tool more intuitive and usable for teachers and administrators.

And when I asked about recent developments, one CEO described the gamification elements they have built into the system. "We were against extrinsic [motivation] in the beginning", he said, "we didn't intend to do this [add badges] at all, but we found that kids (...) would do fist pumps and we'd see it in New York and we'd see it in Denver, and we'd see it in Los Angeles and in Seattle". Since the badges and other game elements are so motivating to learners, he continued, we are adding more.

Across the interviews, the personalized, adaptive part of the technology in question was often associated with equity and closing the achievement gap. "We cater the most" to "the weak learners", said one adaptive learning company, "the top five, top ten percent they will always be top five, top ten, right?" The question becomes how to pull the others up so that they are also doing well, maintaining motivation throughout the course, and not dropping out. Adaptive technology responds with tasks, readings, questions, etc. that are adapted to the learner's individual capacity and capability at the time they are learning.

This company had reduced the drop-out rate in professional training courses by $30 \%$ since implementing adaptive technology. Imagine "if you can just reduce the drop-out rate in the US with about the same effort by what our system has shown". Expressed in economic terms, the high drop-out rates in US higher education impact on the individuals' student debt, and thus "it's the weak students that have biggest fiscal problem that you need to solve for, right?" When I noted that although the feedback mechanisms and personalization associated with adaptive learning clearly had an impact on reducing drop-out rates, there were a number of other reasons for dropping out, such as family pressures, my interview partner said quickly, well yes, but those don't go away. The system of formal learning can, it is implied, only deal with mechanisms internal to learning. Socio-political-culturaleconomic factors fall outside the mandate of learning companies.

The Data Quality Campaign, a non-profit based in Washington, spends a great deal of design effort on clarifying for parents, teachers and students how the data gathered about each individual student (weak and strong) will support their learning experience (see e.g. Fig. 1). 


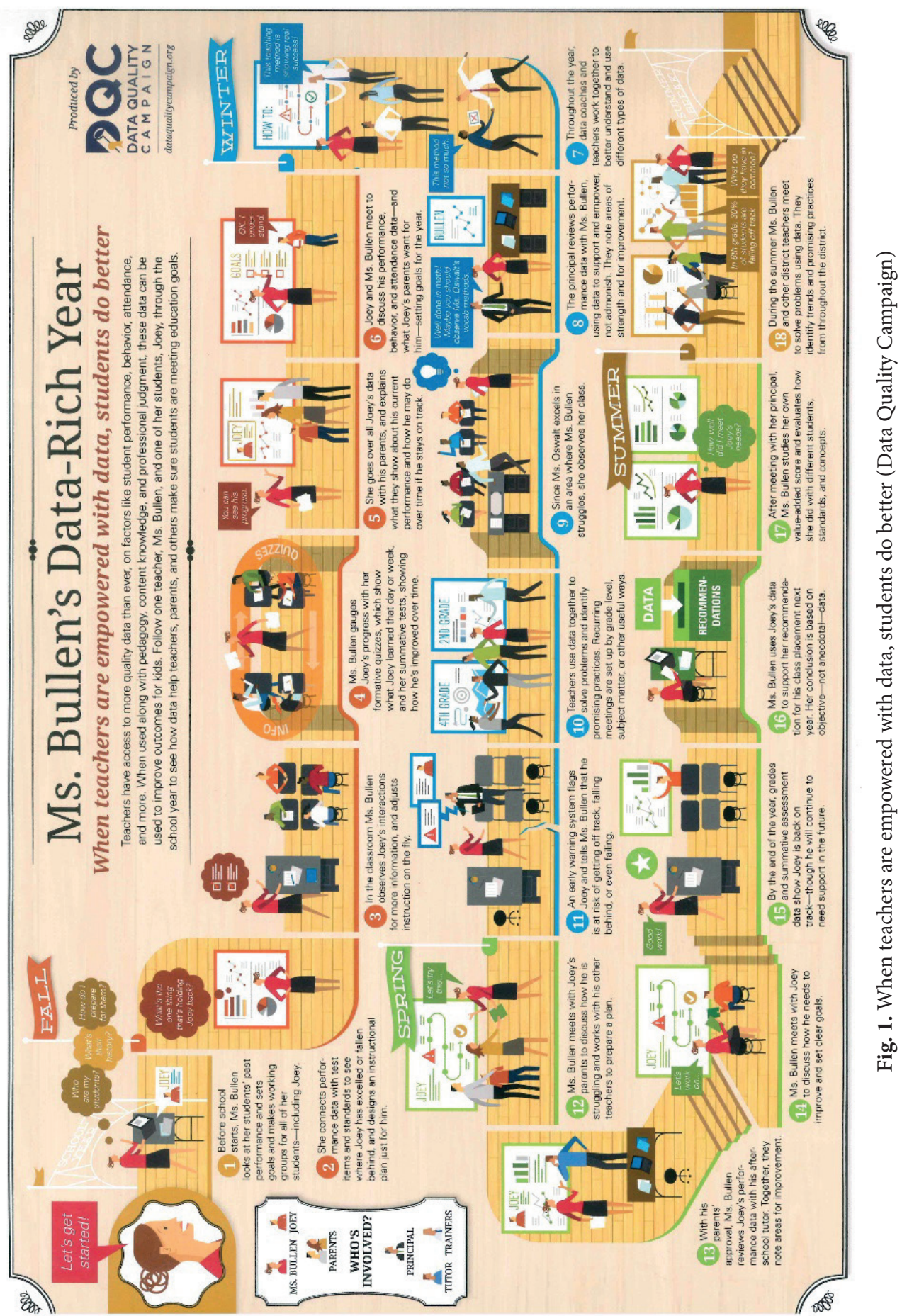


Each of these examples points to similar issues: The problem to be addressed by the educational technology being developed starts with the learner: How to help them like school? How to revise better? How to give every learner a personal tutor? How to help them complete their courses? How to use data to support learners? If we assume all media are designed with an "imagined audience", the primary imagined user in these instances is the individual learner; the learner is driving change at the level of the interface, the design, the algorithms being engineered into the products, the public conversation about student data. In this sense, the individual dimension of technology use is driving change: The overall goal expressed in this discourse is how to improve the individual experience for the individual user. In this sense, struggles over power are being described here: the goal is to empower the learner; to shift the decision-making power from the teacher (who can, in some of these accounts, make school unbearable, and who were, in other accounts, fairly irrelevant to the product design) to the learner, i.e. to shift power from the top to the bottom of the traditional hierarchy; this is an especially acute reflection on power when the learners being described are lowincome, Black or Latinx learners who have traditionally been disadvantaged in formal education.

\section{Discourse 2: School-driven change, the systemic dimension}

"What has eased the process of launching your product?" I asked. "Vision", said one director of professional learning and school design, "So, if you've got thirty schools, that they all understand that their superintendent or their chief academic, whoever it is, knows why they're using it. Because then while implementation might look different, we're all moving towards the same goal and we're all committed to that same goal." In telling me about her background before founding the company, one CEO told me about her experiences as a classroom teacher and founder of a school which became one of the top schools in the US. She attributes a great deal of that success to the school's cross-school focus on analytical reading, academic writing and debate. When she moved on from this school to be Director of Curriculum and Instruction for about 115 schools, she initially thought "oh, we'll just do professional development and teach everyone how to do this, just like we did at [School X]." But in the face of so many competing demands on teachers to do professional development, and the myriad challenges facing schools, especially in disadvantaged neighbourhoods, with the high proportion of students with English as an additional language, few resources, the threat of violence, etc. that was far more difficult than she had expected. She reported thinking: 
"There are just like so many problems here, how do we even begin. And so I was like, we can't do this teacher by teacher, it has to be on a school level, because what I saw was that if a principal said, 'we're doing something', everyone did it. Some people did it well, some people did it poorly, but it got done. And so I thought, ultimately, whatever this education technology is going to be, it has to be something that the school leader can use as a tool for instructional leadership, it has to work for many different students in many different languages, and it has to do something everyone sees as valuable."

Also, when I asked this CEO what she saw as the most innovative things going on in education and technology, her response began with one district's public schools which she sees as being "the most innovative and the most sophisticated in its school reform efforts" in the US. The innovations, she said, are "very tactical": The simple ones are the ones that really work. "The most innovative things happening in schools are teachers rethinking how they spend their minutes in the classroom, who they spend them with, and what they are doing with that person. (...) And technology is merely a tool that they are leveraging to be able to do those things."

Several accounts in the interviews echoed this notion of rethinking how teachers spend their minutes. An adaptive learning company told me that they regard their adaptive learning system as an aid to the teacher: "Because what it can do is that it can actually make sure that all the trivial knowledge that you don't need a teacher to teach, a computer can handle that, and then let the teacher focus on the more difficult things on Bloom's taxonomy." This rethinking impacts on schoolwide practices, and resonates with a story told by another interview participant: Visiting a school the week before we spoke, she observed how teachers split a class into two groups. They did small group teaching with one half of the class, while the other students worked independently on laptops in a shared central space. These small practical changes are, in a way, tactical school reforms, dramatically changing how teachers work, how they interact with students, and how students interact with each other and themselves during their school day.

Also, the Data Quality Campaign told me how student data was used in Washington, DC to create a report card for schools on indicators that were relevant to equity. Looking at the aggregate discipline data, for instance, the school system found that it punished African American students far more readily than white students. It reacted to its data by forming a task force and setting up practices to observe, reflect and change this systematic discrimination. "But, that's more of an outlier than it hopefully will be", my interview partner added.

In these examples, the problem to be addressed starts at the school or district level. If the school is to implement new tools successfully, it helps to be driven by 
an overarching pedagogical vision. Scaling up the process of reforming one school to the whole school district can't be done by individual action, but could be engineered into software. Small tactical changes in practice can shift how teachers and students learn, educate and interact. Legislation encouraging the use of aggregate data from schools can push reform towards greater equity. The primary imagined audience in this discourse is the school: students are aggregated into a student body, teachers are working together for the whole school, legislation and rulings are for the good of all schools in a district or state, reform is related to racist discrimination. This systemic dimension is driving how new software is engineered, how classroom practice is organized, and how conversations around student data unfold, and is thus driving the transformation of education. Again here, specific power relations are implicitly mobilized when the goal is to reform school practices from outwith the school itself: schools' current practices are seen to be problematic, hindering some students from achieving their full potential. External forces, working on the school from beyond its walls and beyond its staff and students, can be used to solve these problems.

\section{Discourse 3: Analytics-driven change, the data dimension}

In one of my final interviews, I mentioned my initial thoughts for this present article, and suggested to my interview partner that his company enacted a "learnerdriven" discourse. "Yeah", he said, "but I would prefer to say that we're outcomedriven". Yes, in reflection and after listening/reading through his interview again, I see both learner-driven and analytics-driven elements. The problem to be solved was, in his statements, how to improve the learning experience for the individual. However, the way to solve the problem is by identifying outcomes, drawing on data to adapt the learning experience to achieve those outcomes, and using the data to measure success. Usage data provides transparency: "we can see what a learner is doing"; teachers couldn't see that before. "When I was going to school", he said, the teacher would ask, "So did you have any problems with what you're reading for today?" They would look around, "No? Alright, great, let's move on". Because no-one dared to raise their hand and admit they had a problem. Now, the teacher can look at the data, can see where most students are struggling, and work on those specific issues.

As analytics have become more important, the employment strategy of the large companies has shifted. Where previously an educational publisher had a host of editors focused on providing long-term, slow-paced support for authors and content, now, while authors and editors remain important, the emphasis has shifted to management consultants who can use analytics about the company's 
performance to manage change, to engineers who program the software to work with data, and to the ongoing fast-paced dynamics of maintaining and improving platforms and working with data. Where previously about $90 \%$ of investment went into the first stage of creating textbooks before the launch, speculated one edtech manager who works with change at a major educational publishing house, now with adaptive technologies about $50 \%$ is now spent correcting, updating, maintaining the systems after the product has been launched. Similarly, companies are disinvesting in complex higher order content which is not conducive to being reworked as (numeric) data. In higher education, for instance, the STEM (science, technology, engineering and mathematics) fields, which have a tradition of using tests frequently, have a much higher demand for edtech products. These resources, which ease the teacher's job of grading and make the student's job of revising for and completing tests more enjoyable, are in far higher demand than materials for courses on, e.g. English literature, which "can quite simply be better with actual books". Logically, a company in which "every last dollar" is going into software rather than books is also shifting its focus to STEM rather than literature.

Almost all the edtech companies I spoke with present reports on their websites on the measurable success attributable to their products. With math product $\mathrm{X}$, for instance, Grade 4 students show 1.55 years growth in math competence in just one year; integrating literacy platform $\mathrm{Y}$ into classrooms closes the achievement gap for low income students by $264 \%$, Black students by $456 \%$ and Hispanic students by $749 \% .{ }^{2}$ Several cooperate with universities to conduct research, others fund independent research on their product, and the larger companies invest in dedicated Research \& Development units. Measurable learning success, closing the achievement gap, and generally using data to demonstrate the advantage of their product over their competitors are key in this field. Whereas textbooks win prizes for design, sales or innovation, there are no prizes for "effectiveness", because there is very little data available on textbooks' impact on learning (cf. Jobrack, 2011: xviii).

One COO told me his product is based on "three learning modalities": Instructional content, i.e. "things that will help you be better at the topic"; memorizing, i.e. "things you need to remember", like Pythagoras theory; and assessment, i.e. "things you need to be assessed on" (formative or summative). What about further modalities of learning such as creativity or critical thinking, I asked. Our platform "is not at a point that we can test you on all of that. So that's not where we excel",

2 To ensure the semi-anonymity of my interview partners, I have not cited the source of these effectiveness studies; the figures are those quoted in the reports. 
he replied. It excels at exams, in particular numeric exams. Similarly, although the Data Quality Campaign takes on a broad understanding of "data", arguing that teachers have always acted on data when they have been acting on their observations of students in class, the prevailing understanding of "data" in their materials (see Fig. 1 above) refers to measurable, numerical, chunked items. A literacy app may provide space for comments, thoughts and reflections, and thus enable the human dimension of student-teacher interaction, but these text snippets do not feed into the adaptive component of the app. The texts are created within the app but they are not "data".

In this sense, data are central, and particular things count as data. The central problem to be addressed is poor achievement on testable tasks. The issue for the organizations - as realized in this discourse - is how to make data visible/ actionable, and how to improve the visible data on achievement, e.g. test scores, years of math progress, or Lexile measures. In this discourse, the material dimension of data is driving change: creativity and creative critical appraisal cannot be measured, and thus do not count as data at the moment. If investment is being so strongly channelled into digitally manageable courses and specializations, then the 'bookish' fields - of complex creativity and critique - are seeing disinvestment. With the data dimension, we see the clearest realisation of an apolitical stance (data makes the process transparent; data is presented as neutral), yet also the most visible form of hard power: job losses.

\section{The complexities of privatization, education and learning}

The previous section explored the first of the two questions guiding this article: What is driving change in contemporary educational media? It identified three (overlapping, interwoven, yet distinct) discourses: learner-driven, school-driven and data-driven change. In this section, I draw on these three discourses to think through the second question: Are new actors/technologies shaping a novel educational hegemony, and if so, what does this hegemony look like? This section suggests that one guiding concept knots the three discourses together, and reflects on broader implications for education and today's socio-political order.

Many of the concerns about the new actors entering the field of education through media/technology products relate to their origins in private, for-profit companies (Apple, 2006; Ball and Youdell, 2009). Fred van Leeuwen, General Secretary of Education International, captured a core dichotomy in his foreword to a report on Hidden Privatisation in Public Education: 
To put it in the starkest possible way: is education about giving each child, each young man or woman, the opportunity to develop his or her full potential as a person and as a member of society? Or is education to be a service sold to clients, who are considered from a young age to be consumers and targets for marketing? (van Leeuwen in Ball and Youdell, 2009: 3f)

This stark contrast is, however, if we look closely at the accounts given above, arguably too binary. My interview partners are strong advocates for educational equality, for supporting learners to develop their potential and achieve success in society. Their accounts do not see children as consumers and marketing targets. It is also quite clear, given current privacy regulations, that marketing is not the way to monetize data generated from school education. Yes, the private companies are oriented to making a profit - and there are deep ambivalences about for-profit actors entering public education - but the relationship between profit, students and potential seems more complex than van Leeuwen's questions imply.

Looking at the interviews, the issue is not about an either/or option (opportunity vs. marketing), but about (re-)defining the "good" of education. First, part of education does become a service to be sold to clients, where the clients are school boards, school districts, etc. rather than students. But the service aims precisely to develop a young person's full potential as a learner. Privatization is thus not opposed to, but entangled with, classic conceptions of good education. Second, whereas there were no non-profit textbook publishers in the US before the emergence of OER, some of the most successful edtech products today are produced by non-profit entities. These companies tend to offer their main learning product free, with additional professional development components offered for a fee. The $\mathrm{CEO}$ of the non-profit edtech company included in this study was very clear that education should be understood as a "public good" and supported by a different economic logic than for-profit companies can realise. Again, educational technology is not opposed to, but entangled with, classic conceptions of good education.

As this previous paragraph suggests, however, "learning" emerges in the interviews as a key word when talking about education. Most participants I spoke to are clear in their terminology: They are speaking about learning, rarely about education. A theory of learning tends to be engineered into the software, where learning is understood as a concrete task, specific learning outcomes can be listed, measured, assessed, and the assessments compared to other measures (other classes, other children or the child's previous work), rather than theories which imagine learning as an open, exploratory, emancipatory and social practice. The material affordances of digital technology lend themselves well to thinking in terms of independent learning and measurable learning outcomes. As Gert Biesta (2013) reminds us, however, learning is not education. Education can be thought of as a whole complex process 
including, but not reduced to, learning, and always involving risk: "Yes", writes Biesta, "we do educate because we want our students to learn and achieve", but that does not mean that a "situation in which there is a perfect match between input' and 'output' is either possible or desirable". Instead, there is always a "risk" in education, "because education is not an interaction between robots but an encounter between human beings" and "because students are not to be seen as objects to be moulded and disciplined but as subjects of action and responsibility" (Biesta, 2013: 1). Education is not "a product to be packaged, automated, and delivered" (Veletsianos and Moe 2017). In digital education, a "pedagogy of uncertainty" (Britzman (2009: xi) retains its value, and "the mystery of what it means to teach, or to learn" has not been (cannot be) solved (Ross et al., 2014: 58).

This distinction between learning and education relates to the stories above of dividing the task of teaching between teachers and software: In those stories, teachers delegate some aspects of teaching/learning to the tool, and spend more intense time with smaller groups of students on the other aspects of education. This will not always be a risky space, but the space opens the possibility for unexpected human encounters: where teachers encourage critical reflection on the digital resources or where peers interact with one another; where uncertainty, risk and mystery are welcome; where it is about, as van Leeuwen says above, developing students' "full potential as a person and as a member of society" rather than [simply] their full potential as a learner.

However, current educational policy focuses increasingly not on learning as a part of education, but on learning rather than education. In this sense, the fundamentally political questions of "what education is and should be" is being softly resolved in favour of learning. Driven by educational psychology, large-scale international surveys such as the Programme for International Student Assessment (PISA), Trends in International Mathematics and Science Study (TIMSS) or the International Computer and Information Literacy Study (ICILS), and national/ federal curriculum reform, attention is shifting from education to pre-defined, measurable and risk-free learning outcomes. My interview partners, while often explicitly orienting to equality and social justice, also implicitly orient to (measurable) learning, and their accounts are thus intimately entangled with today's general discursive shift. In this sense, the explicit political struggles noted above, e.g. empowering students or enacting tactics for school reform, take place on a discursive terrain in which pre-defined learning outcomes, and the 'datafied' learner, constitute the (almost) unquestioned educational hegemony.

Before turning to how this educational hegemony is entangled with broader shifts in the socio-political order, I want to reflect on one specific point of contes- 
tation: the potential roles for the teacher in digital education. Teachers, as I noted above, are no longer the main gatekeepers between student and media provider, they have been 'backstaged'. So, a first concern is whether the widespread use of high quality, content-rich, interactive, adaptive technologies is turning the teacher into a behaviour manager. In this scenario, students work independently and in groups on tasks led and structured by the technological tools at their disposal. The students take on responsibility for their education and their learning. The teachers' primary task is to keep students on task, and stop misbehaviour. This deprofessionalization would be a major 'disruption' to current educational practice. Some of the interview partners quite clearly voiced concerns about teachers' competencies. They were quick to acknowledge that some teachers in schools are excellent, but "the majority" are performing poorly. According to this view, most teachers do not offer students a higher quality interaction than the software does. In fact, the negative impact teacher talk can have on students is eliminated if the software is used more frequently. This second scenario chimes with longstanding discussions in US education on "teacher-proofing" the curriculum (cf. Apple 2000: 70 ), in which the goal is to plan a curriculum so tightly and tie it so intimately to textbook content, accountability or performance management, that even the most "incompetent" teacher can't damage the students. A disdain for teaching as a profession - which can also be tied to gendered labour (Apple, 1986) - undergirds this scenario. It dominates some public conversations, but is also hotly contested.

Or, a second scenario, does the discourse of learning (rather than education), which is so predominant in the interviews, position teachers as highly skilled professionals, but nevertheless reduce education to one specific aspect, i.e. achieving pre-defined learning outcomes? Interactive technologies would, in this view, finally enable the teacher to take on the role of facilitator which constructivist learning theories from Piaget to Vygotsky have long been advocating. The teacher's role is then primarily to guide successful, efficient, effective, engaging, active learning. The teacher - as learning resource - helps students meet the demands of the world as it is, but does not interrupt current common-sense, critique the digital technologies, or open a space for the risk of emergent responsibilities and action. Teaching to the test is hard to avoid in this second scenario, since the priority lies in achieving high test scores, good grades and measurably improved learning outcomes. The "fiscal" reason for supporting students to learn better and achieve good grades is to ensure they complete the course, reducing overall drop-out rates and student debt. The impact of teachers on course completion and student success is understood as internal to learning. Other factors (economic pressures, unpaid care work, family responsibilities, getting enough food and water to concentrate 
throughout the day, etc.) would not be addressed by teachers. In this sense, the individuality of the learner is also internal to their learning; their individual life situation is rarely made relevant to how the technology will work (or not work) for them. The three discourses outlined in the preceding section all play strongly into this 'learnification' scenario. Rather than shaping a 'novel' educational hegemony, they are strengthening a common sense (of education as learning) which has become almost self-evident (and thus hegemonic) today. This hegemony undergirds Biesta's concern that as the teacher's role shifts from teacher to facilitator we "give up on the very idea of education" (Biesta, 2013: 46).

Third, some lines of flight flowing away from this hegemony are, however, also visible in the interviews. They illustrate the ongoing struggles over what counts as education, which are playing out, not only among educational theorists, but also among edtech developers. Digital resources used in a split-class format, for instance, in which half the class work independently on their computers/tablets with individualized learning, while the other half receive smallgroup instruction with their teacher, position the teacher (and teaching) as core to the educational experience. These products aim to foster closer, more intense, encounters among teacher and students than are currently enabled by the public/state school system with its large classes. They create a space in which risk can be welcomed, because the core of this space is one in which students and teachers address one another, and in which teachers or students can interrupt the pre-defined learning outcomes or side-track with personally important issues; there is space in which teaching can bring "something radically new" (Biesta, 2013: 53) to students; in which teachers can focus on listening to and caring for students (Doxtdator, 2017; Prinsloo, 2016); or in which teachers can bring uncomfortable and "difficult knowledge" (Britzman, 1998: 117) to the classroom which may lead to students producing "simply thrilling lines of flight" in unexpected directions (Adams St. Pierre 2008: 193). In this sense, digital education prefigures a new assemblage of human and non-human actors, since students receive individualised feedback from not only their teachers and peers, but also from software. Education, in this sense, is about the whole person, it includes space to reflect together on the technology and to take a critical distance to the media being used. It enables learning not just in the medium but about the medium; and learning not just about a subject but from one another (Todd, 2003). And it enables teachers to bring something external to the learning event into the exchange. In this scenario, which was a core scenario for my interview partner in the non-profit company, students do more than learn, and the teacher is quite explicitly an educator. 


\section{Educational hegemony: data, policy and practice}

The hegemonic understanding of education as learning is in turn entangled with - i.e. is constituted by and constitutes - broader shifts in the socio-political order, as datafication becomes increasingly prominent across our materialdiscursive lives. Discussions on datafication, i.e. the representation of social life in computerised data, abound in the fields of medicine, crime prevention, finance, media and politics (Hepp, 2016; O’Neill, 2016; Süssenguth, 2015). Datafication is linked to concepts such as the "quantifiable self" and the "transparent society" and to an increasing (self-)surveillance in our world today (Han, 2012). Some observers suggest that big data is undermining democracy with the threat of an "algocracy" (Danaher, 2014); at the very least, algorithmic filtering is a "human rights issue" (Tufekci, 2014). This critique is accompanied by observations of how data play into the tensions among power, liberation, exploitation and struggles for equality and social justice (Emejulu and McGregor, 2016; Jordan, 2015).

Given the extensive data collected during formal schooling, there is now also an emerging body of work on datafication in education, and how data is entangled with shifting socio-cultural, political, economic, historic and material orderings and normalisations. Datafication brings, for instance, a new logic of investment into everyday school practice (Thompson and Cook, 2016); data tools prefigure techniques of digital educational governance (Williamson, 2016); data play into "the surveillance and performative culture of accountability" which "both affirms, legitimates and seduces through discourses of quality while increasingly regulating and governing" education (Roberts-Holmes and Bradbury, 2016: 600). Data flows and platforms are seen here as policy instruments for controlling education, with significant (detrimental) impacts on teachers' professionalization (Selwyn 2016). Again, these studies aim to provide a necessary critical reflection of educational data practices, including the "hidden mediators" who are becoming more powerful (Hartung 2016). However, this focus on hegemony tends to neglect the accompanying lines of flight (cf. Selwyn, Henderson, and Chao, 2015).

\section{Concluding words}

Contestation over the role of the teaching profession is, for instance, one area where struggles over politics, exploitation and the power to shape change become visible. Deciding which school practices and pedagogies should be fostered and implemented to achieve the promises of digital education means deciding what 
the teacher's role is in relation to digital technologies, in particular those data technologies which adapt to the individual learner's needs. This paper has suggested that, far from claiming that technology is neutral, edtech providers often clearly describe how their product is participating in the "fundamentally political questions" over what counts as good education (Selwyn, 2012: 217). This includes their expectations of teachers, and the practices which are engineered into the products, i.e. the software's socio-material-discursive affordances, the kinds of knowledge, interaction and action in which a product invites its users to engage. One conclusion from this study is that, as these new data actors emerge, and established actors reorient to develop new data technologies, they aim to shape educational policy, practice and pedagogy in particular ways. The change they envision is driven by an orientation to learners, to schools and/or to data analytics.

In sum, this paper has highlighted ways in which digital education is more complex than the binary option of either offering young people up to private interests as consumers and marketing targets or developing their full potential as people and members of society. Clarifying the expectations of a society for how teachers can relate to technology and data in different spaces of schooling - and advocating for how they should relate - will shape the kinds of education and/or learning which young people experience in schools. Thus far, this conversation is only happening on the margins of public discourse on education and datafication. Leaving these expectations under the radar will also shape how young people experience school, since it delegates decisions on how to imagine future teacher roles to the educational technology developers and to the material affordances of the tools they are designing.

\section{References}

Adams E., Pierre St. (2008). Deleuzian concepts for education: The subject undone. [In:] I. Sementsky (ed.). Nomadic Education: Variations on a Theme by Deleuze and Guattari, Rotterdam, pp. 183-196. Adams E., Pierre St. (2011). Post qualitative research: the critique and the coming after. [In:] N.K. Denzin, Y.S. Lincoln (eds). The SAGE Handbook of Qualitative Research, Thousand Oaks, pp. 611-626.

Apple M.W. (1986). Teachers and Texts: A political economy of class and gender relations in education. New York.

Apple M.W. (2000). Official Knowledge: Democratic Education in a Conservative Age. $2^{\text {nd }}$ ed. New York.

Apple M.W. (2006). Educating the "Right" Way: Markets, Standards, God, and Inequality. New York. Ball S.J., Youdell D. (2009). Hidden Privatisation in Public Education. Brussels. http://download.ei-ie. org/docs/IRISDocuments/Research\%20Website\%20Documents/2009-00034-01-E.pdf. 
Biesta G. (2013). The Beautiful Risk of Education. London.

Britzman D. (1998). Lost Subjects, Contested Objects: Toward a Psychoanalytic Inquiry of Learning. Albany. New York.

Britzman D. (2009). The Very Thought of Education: Psychoanalysis and the Impossible Professions. Albany.

Clapp E.P, Ross J., Ryan J.O., Tishman S. (2017). Maker-Centered Learning: Empowering Young People to Shape Their Worlds. San Francisco.

Danaher J. (2014). Rule by algorithm? Big data and the threat of algocracy. [In:] Philosophical Disquisitions. http://philosophicaldisquisitions.blogspot.de/2014/01/rule-by-algorithm-big-data-andthreat.html [28 Apr 2017].

DeVault M.L., McCoy L. (2006). Institutional Ethnography: Using interviews to investigate ruling relations. [In:] D.E. Smith (ed.). Institutional Ethnography as Practice. Oxford. pp. 15-44.

Dezuanni M., O'Mara J., Beavis C. (2015). "Redstone is like electricity": Children's performative representations in and around Minecraft. "E-Learning and Digital Media" Band 12, Heft 2, pp. 147-163.

Doxtdator B. (2017). Maybe we're not afraid: on Edtech's inability to imagine the future. Retrieved 28 April, 2017, from http://www.longviewoneducation.org/maybe-not-afraid-edtechs-inabilityimagine-future/.

Emejulu A., McGregor C. (2016). Towards a radical digital citizenship in digital education. "Critical Studies in Education", pp. 1-17.

Han B.-C. (2012). Transparenzgesellschaft. Berlin.

Hartung S. (2016). Between assessments, digital technologies and big data: The growing influence of 'hidden' data mediators in education. "European Educational Research Journal" Band 15, Heft 5, pp. 523-536.

Hepp A. (2016). Kommunikations- und Medienwissenschaft in datengetriebenen Zeiten. „Publizistik“, Band 61, Heft 3, pp. 225-246.

Hodel J. (2013). Verkürzen und Verknüpfen. Geschichte als Netz narrativer Fragmente: Wie Jugendliche digitale Netzmedien für die Erstellung von Referaten im Geschichtsunterricht verwenden. Bern.

Höhne T. (2015). Technologisierung von Bildungsmedien. „Die Deutsche Schule“ Band 2015, Heft 1, pp. $8-19$.

Jobrack B. (2011). Tyranny of the Textbook: An Insider Exposes How Educational Materials Undermine Reforms Lanham. Maryland.

Jordan T. (2015). Information Politics: Liberation and Exploitation in the Digital Society. London.

Laclau E. (2005). On Populist Reason. London.

Law J., Afdal G., Asdal K., Lin W., Moser I., Singleton V. (2013). Modes of Syncretism: Notes on noncoherence. "CRESC Working Paper" 119.

Lenz Taguchi H. (2012). A diffractive and Deleuzian approach to analysing interview data. "Feminist Theory" Band 13, Heft 3, pp. 265-281.

Macgilchrist F. (2011). Schulbuchverlage als Organisationen der Diskursproduktion: Eine ethnographische Perspektive. „Zeitschrift für Soziologie der Erziehung und Sozialisation“ Band 31, Heft 3, pp. 248-263.

Macgilchrist F. (2017). Digitale Schulbücher: Chancen und Herausforderungen für den politischen Fachunterricht. [In:] H. Gapski, M. Oberle, W. Staufer (eds). Medienkompetenz als Herausforderung für Politik, politische Bildung und Medienbildung. Bonn.

McGraw-Hill Education. (2017). McGraw-Hill Education Q4-2016 Update. 
Okamoto K. (2013). Making Higher Education More Affordable, One Course Reading at a Time: Academic Libraries as Key Advocates for Open Access Textbooks and Educational Resources. "Public Services Quarterly" Band 9, Heft 4, p. 267-283.

O’Neill C. (2016). Weapons of Math Destruction. New York.

Pangrazio L. (2016). Reconceptualising critical digital literacy. Discourse. "Studies in the Cultural Politics of Education" Band 37, Heft 2, pp. 163-174.

Prinsloo P. (2016). Failing our students: Not noticing the traces they leave behind, Open distance teaching and learning. Retrieved 28 April, 2017, https://opendistanceteachingandlearning.wordpress. com/2016/11/07/failing-our-students-not-noticing-the-traces-they-leave-behind/.

Roberts-Holmes G., Bradbury A. (2016). Governance, accountability and the datafication of early years education in England. "British Educational Research Journal" Band 42, Heft 4, pp. 600-613.

Ross J., Sinclair C., Knox J., Bayne S., Macleod H. (2014). Teacher Experiences and Academic Identity: The Missing Components of MOOC Pedagogy. "MERLOT Journal of Online Learning and Teaching” Band 10, Heft 1, pp. 57-69.

Sammler S., Macgilchrist F., Müller L., Otto M. (2016). Textbook Production in a Hybrid Age: Contemporary and Historical Perspectives on Producing Textbooks and Digital Educational Media. Eckert.Dossiers 6.

Selwyn N. (2012). Ten suggestions for improving academic research in education and technology. "Learning, Media and Technology" Band 37, Heft 3, pp. 213-219.

Selwyn N. (2016). "There's so much data": Exploring the realities of data-based school governance. "European Educational Research Journal" Band 15, Heft 1, pp. 54-68.

Selwyn N., Henderson M., Chao S.-H. (2015). Exploring the role of digital data in contemporary schools and schooling - '200,000 lines in an Excel spreadsheet'. "British Educational Research Journal" Band 41, Heft 5, pp. 767-781.

Selwyn N., Nemorin S., Johnson N. (2016). High-tech, hard work: an investigation of teachers' work in the digital age. "Learning, Media and Technology" pp. 1-16.

Strommel J. (2014). Critical Digital Pedagogy: a Definition. Hybrid Pedagogy. "A Digital Journal of Learning, Teaching and Technology”, http://www.digitalpedagogylab.com/hybridped/criticaldigital-pedagogy-definition/.

Süssenguth F. (ed.). (2015). Die Gesellschaft der Daten. Bielefeld.

Thompson G., Cook I. (2016). The logic of data-sense: thinking through Learning Personalisation. "Discourse: Studies in the Cultural Politics of Education". pp. 1-15.

Todd S. (2003). Learning From The Other. Albany.

Tufekci Z. (2015). What Happens to \#Ferguson Affects Ferguson: Net Neutrality, Algorithmic Filtering and Ferguson, 14 August 2014, https://medium.com/message/ferguson-is-also-a-net-neutralityissue-6d2f3db51eb0.

Veletsianos G., Moe R. (2017). The Rise of Educational Technology as a Sociocultural and Ideological Phenomenon. "EduCauseReview". http://er.educause.edu/articles/2017/4/the-rise-of-educational-technology-as-a-sociocultural-and-ideological-phenomenon.

Williams R. (1977). Marxism and Literature. Oxford.

Williamson B. (2016). Digital education governance: data visualization, predictive analytics, and 'realtime' policy instruments. "Journal of Education Policy" Band 31, Heft 2, pp. 123-141. 